\title{
SOME ASPECTS OF THE DISTRIBUTION OF MICROFAUNA IN THE ARCTIC
}

\author{
Marie Hammer
}

K

NOWLEDGE of the composition and distribution of the microfauna of Greenland and arctic North America has slowly accumulated during the past twenty years. By 1944 when the study of the microfauna collected by the expeditions of Knud Rasmussen, Lauge Koch, and others was completed (Hammer, 1944), the microfauna of Canada was still unknown, there was no apparent relationship between the microfauna of the United States and Europe, and it was not possible to deduce the origin of the Greenland fauna. Since then investigations have been carried out in northern Canada, including Ellesmere Island, in Alaska, and in Peary Land, and Søndre Strømfjord in Greenland. These have shown that the two groups of animals discussed in this paper, the oribatids and the collemboles, are well suited for zoogeographical studies; their distribution may settle the problem of the origin of the true fauna of Greenland, as these non-mobile animals which belong to the soil have little chance of straying from their particular biotope.

Previous research workers found that some of the animal groups in Greenland originated in North America, whilst others came from Europe. All these animals were, however, mobile and could travel long distances, either alone or with external help. Mammals crossed the ice from North America; birds flew to Greenland from both Europe and North America; some insects, such as butterflies, came from North America across the narrower straits, while others crossed the sea, partly unaided, partly carried by air currents. Some spiders must have travelled in this way, while others must have survived the Ice Age in Greenland. This interchange of fauna took place in both warm and cold climatic periods and is still continuing. Thus Greenland has obtained a very varied fauna from which the exotic elements have gradually disappeared or have found refuge in remote valleys or on mountains, depending on their requirements.

It seems unlikely that the elements of the microfauna have spread in this way as they are earth-bound and belong to the soil. The narrow sphere to which each is restricted is well shown from another part of the Arctic. At Yellowknife, 5 samples were taken from each of the two biotopes in a cushion of alternating lichens and Polytricbum, about one square metre large, growing on a flat rock. The Polytrichum harboured a collembolan species, Lepidocyrtus violaceus (Geoffroy), of which 11 individuals in all were taken in 3 of the 5 samples; the lichen biotope, however, contained another Lepidocyrtus species, L. cyaneus Tullb. var. albicaudatus Hammer, of which there were 34 individuals distributed throughout the 5 samples; this species was not found elsewhere in Canada. 
In no case was the species characteristic of one biotope found in the other, although the two vegetation types were growing together. The remaining collembolan fauna was rather varied. Such intense specialization does not necessarily prove that these animals never leave their own biotope although this is unlikely to happen, and it might prove fatal to many species.

Figure 1 shows areas in which microfauna have been collected with a Berlese funnel. Thule, Frobisher, and northern Quebec should probably be omitted, as practically no animal life was found and the sampling was presumably erroneous. About 750 samples have been taken from Greenland. Alaska and northern Canada have been less closely studied and a total of only 670 samples has been obtained. Greenland is poorer in species, as might be expected because of the more homogeneous conditions and the isolation; about 65 species of oribatids and 50 species of collemboles are known.

The oribatid and collembolan fauna of Canada and Greenland are compared in Figs. 2 and 3, according to the distribution of the species. No less than 86.5 per cent of the oribatid fauna of Greenland is known from Europe (Hammer, 1952a, p. 82) and 44.1 per cent from Canada and Europe. In Canada 55.6 per cent of the oribatid fauna is common to Europe, and 24.5 per cent has also been found in Greenland. The oribatid fauna of both Greenland and Canada thus corresponds closely to that of Europe. The circumpolar species in both countries are the same. There are 2 species found in Greenland only, Jugoribates gracilis Sell. and Belba trägårdbi Grav. and 38 species so far found in Canada only. A few of the species found in Canada had previously been found in the United States only.

Similarly a comparison between the collemboles of Canada and Greenland (Fig. 3) shows that 84.8 per cent of the collembolan fauna of Greenland is known from Europe (Hammer, 1953a, p. 80) and 58.7 per cent has also been found in North America. Only 54.7 per cent of the Canadian collembolan fauna is known from Europe and 28.9 per cent

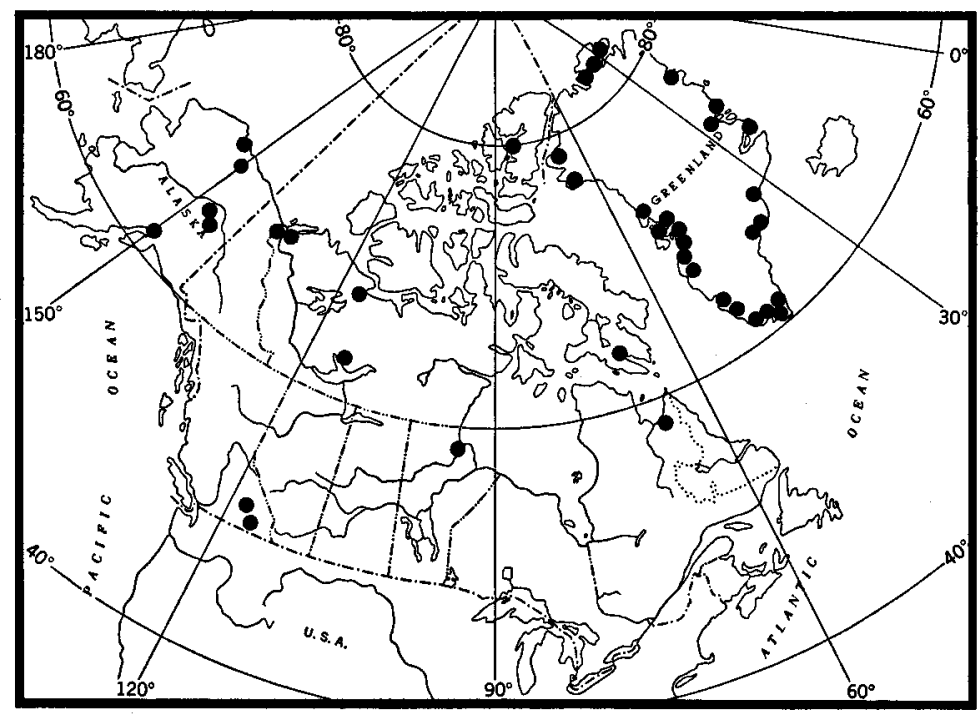

Fig. 1.

Areas in which microfauna has been collected with the Berlese funnel. 


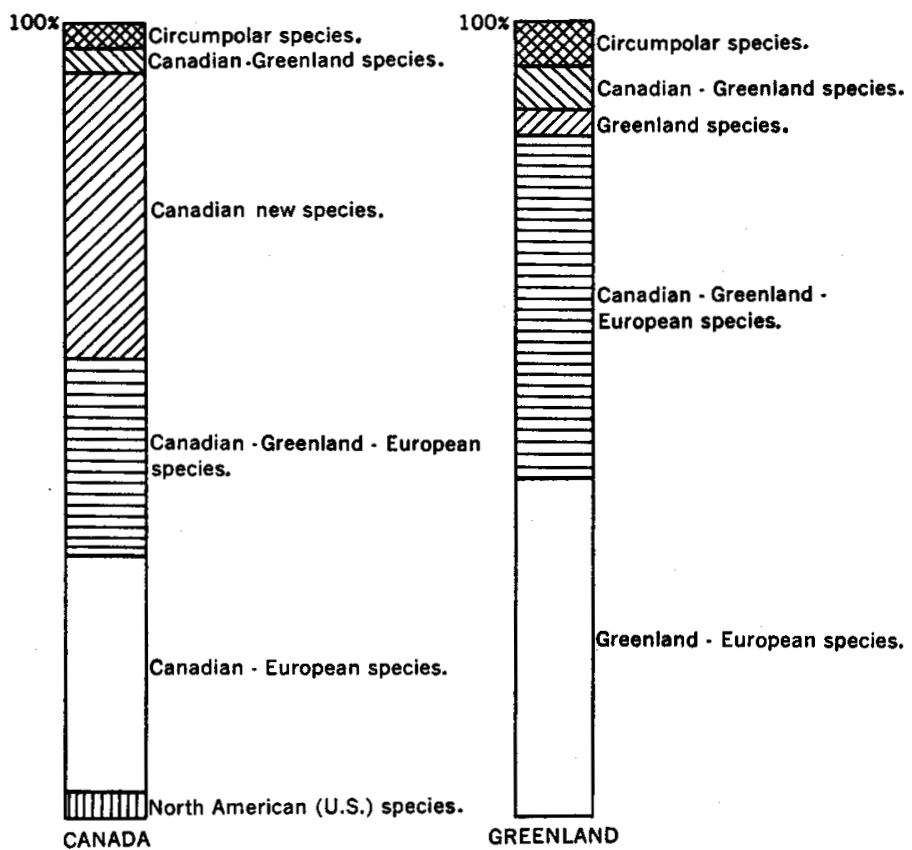

Fig. 2. A comparison between the oribatid fauna of Canada and Greenland.

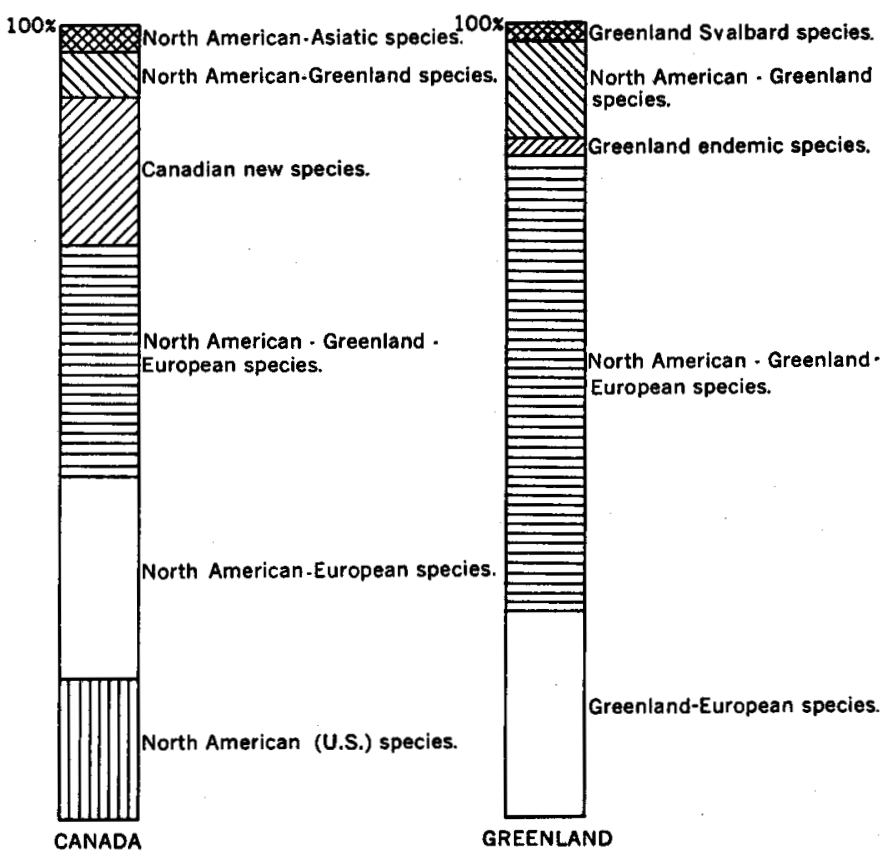

Fig. 3. A comparison between the collembolan fauna of Canada and Greenland. 


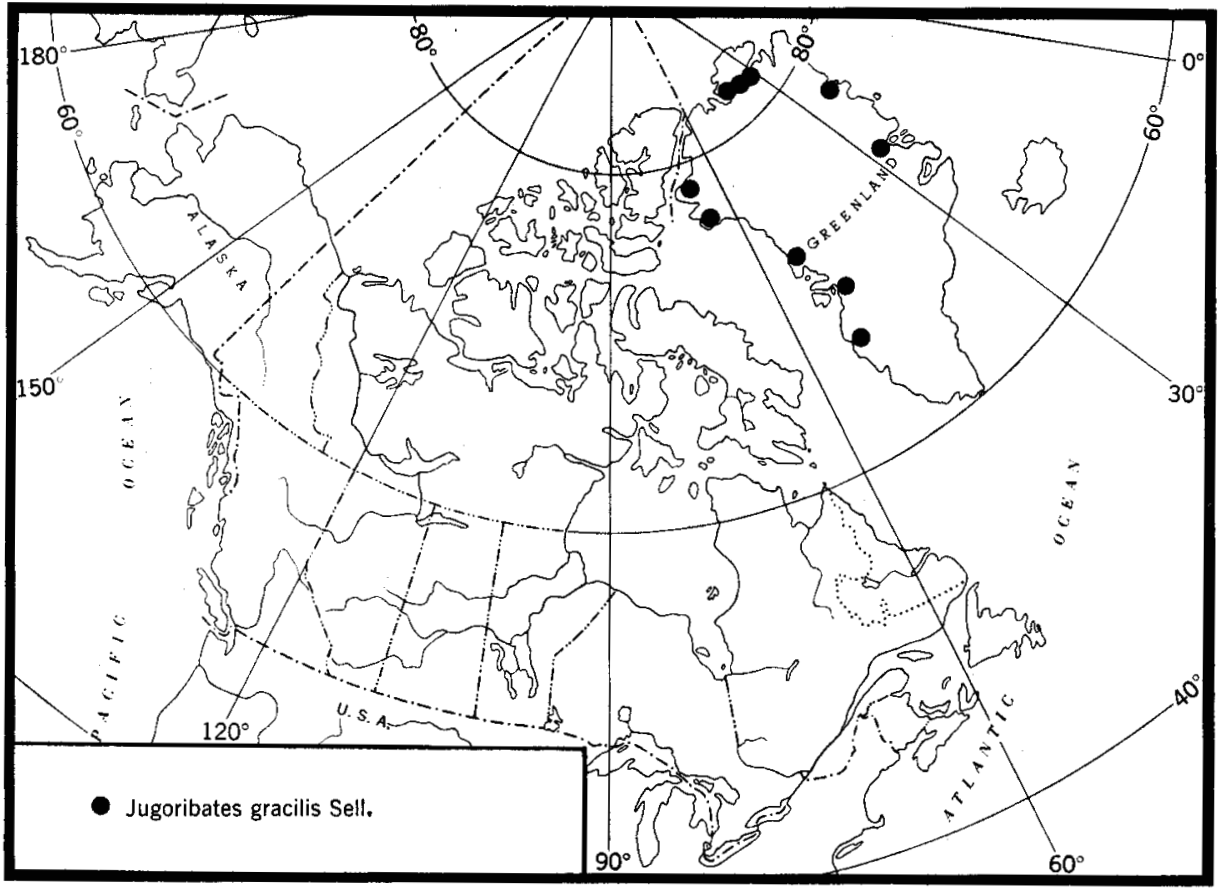

Fig. 4. Distribution of Jugoribates gracilis Sell.

is also found in Greenland. A small group of species is common to North America and Greenland only. Greenland has a small percentage in common with Svalbard and Canada has an equally small percentage in common with Asia. Both Canada and Greenland have some species that are restricted to the one country. In Canada this group comprises 19.5 per cent of the total. In addition, 17.6 per cent of the Canadian collemboles are also known from the United States.

The greater part of the microfauna of Greenland is common to Europe and Canada. As knowledge of the microfauna of Canada and Greenland is extended this percentage will presumably increase but the ratio is unlikely to change materially. Europe, Greenland, and northern North America thus form a single, large, very old faunal area, which was an entity when the animals occupied it. Since then there have been many changes and the animal life has had to adapt itself to periodic climatic fluctuations. For example, the comparatively rich microfauna in the moist valleys of southern Greenland must be considered a relic fauna from a warmer period. Elsewhere in Greenland other climatic changes have also left their mark on the fauna.

Among the oribatids, Jugoribates gracilis has been found in Greenland only and its range is indicated in Fig. 4. It is widespread in Peary Land (Hammer, 1954, p. 21) where it is the commonest oribatid and is particularly numerous in fell-fields ${ }^{1}$ and similar dry biotopes. It is also known on the east coast of Greenland, from Mørkefjord in about $77^{\circ} \mathrm{N}$. (Hammer, 1954,

1Rocky barren ground with scattered cushions of small plants. 


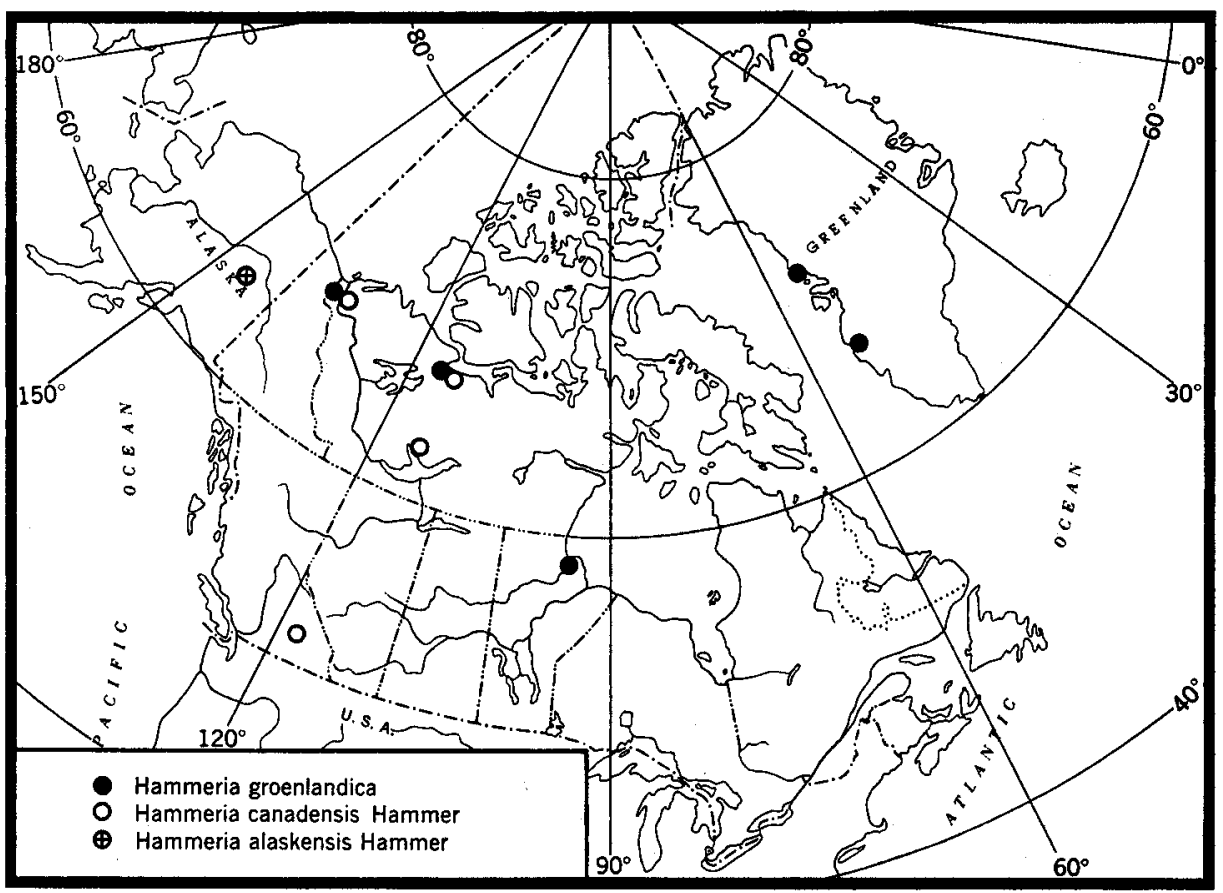

Fig. 5. Distribution of the genus Hammeria.

p. 22) and from Ymers $\varnothing$ in the Kejser Franz Josephs Fjord area (Hammer, 1946 , p. 21). On the west coast it has been found in Inglefield Land, $79^{\circ} \mathrm{N}$., at Kanak, and at Upernavik. Farther south it is known from Disko Bugt (Strenzke, 1952, p. 96), and the desert-like interior of the Søndre Strømfjord area (Hammer, 1952b, p. 410). In all these areas precipitation is low: about $125 \mathrm{~mm}$. in Peary Land, $110 \mathrm{~mm}$. on Ella $\varnothing, 120 \mathrm{~mm}$. in Søndre Strømfjord, and $230 \mathrm{~mm}$. at Upernavik. This oribatid must, therefore, be considered a relic from a former period when the climate was much drier. It is still questionable whether $J$. gracilis is really endemic to Greenland. A comparison with other species suggests that it may also live in the northernmost Canadian islands, and perhaps in Alaska.

The genus Hammeria (Fig. 5) was first found in west Greenland near Upernavik, where Sellnick described H. groenlandica (Hammer, 1944, p. 46) in fell-field and moor vegetation. Recently it has been found in the arid, inner part of Søndre Strømfjord (Hammer, 1952b, p. 410). In Canada $H$. groenlandica is known from arctic localities such as the Richardson Mountains, Coppermine, and Churchill and only from the driest biotopes (Hammer, 1952a, p. 52). Another species of the same genus, H. canadensis Hammer, has been found in Canada together with $H$. groenlandica at Coppermine, Reindeer Depot, and farther south at Yellowknife, and in the Rocky Mountains (Hammer, 1952a, p. 53). This species is also found in bogs. A third species, H. alaskensis Hammer (Hammer, 1955, p. 22) is known from Alaska, and other closely related species, Pelops minnesotensis, P. latipilosus 


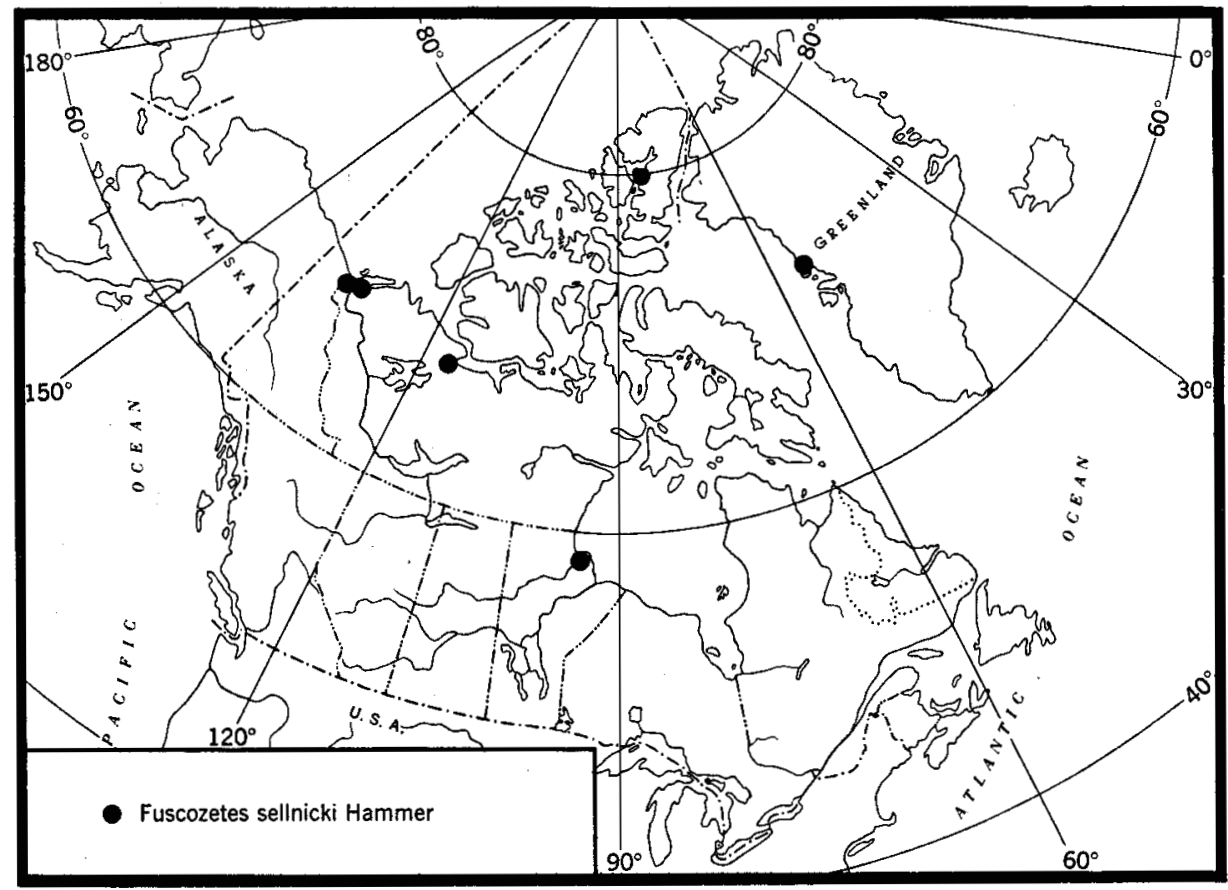

Fig. 6. Distribution of Fuscozetes sellnicki Hammer.

and Eupelops monticolus have been described from the United States by Ewing. The whole genus is thus markedly American, a single species having spread to west and southwest Greenland, where, like Jugoribates gracilis, it is perhaps a relic from a warmer and drier period.

Fuscozetes sellnicki Hammer (Fig. 6) has been found in Canada in the Richardson Mountains, at Reindeer Depot, Coppermine, and Churchill, mainly in wet moss, but also in heath biotopes. A single individual was found on Ellesmere Island in a cushion of Stellaria sp. In Greenland it is known only from Upernavik, a few individuals having been taken from bogs or bog-like biotopes, and two individuals from heath vegetation.

In Greenland Peloribates pilosus Hammer is known from Ella $\varnothing$ where it is found on lake banks, in great numbers in a bog, and occasionally in heath vegetation. $P$. pilosus is rather common in the interior of Søndre Strømfjord in heath vegetation. Three individuals have been found in Canada, at Churchill, in a thin layer of moss. So little is known about the distribution of this species that no conclusions can be made as to the routes or way by which it spread. Another species of the same genus, $P$. canadensis Hammer, is known from Canada and Alaska; and a third species $P$. alaskensis Hammer (Hammer, 1955, p. 18) is known from Alaska (Fig. 7).

Eremaeus translamellatus Hammer (= E. oblongus C. L. Koch borealis n. subsp.) has only been found in Greenland in the Disko Bugt area (Strenzke, 1952, p. 94). In Canada it is known from moor vegetation, lichen heaths, and similar biotopes in the Richardson Mountains, at Reindeer Depot, and at Coppermine (Fig. 8). 


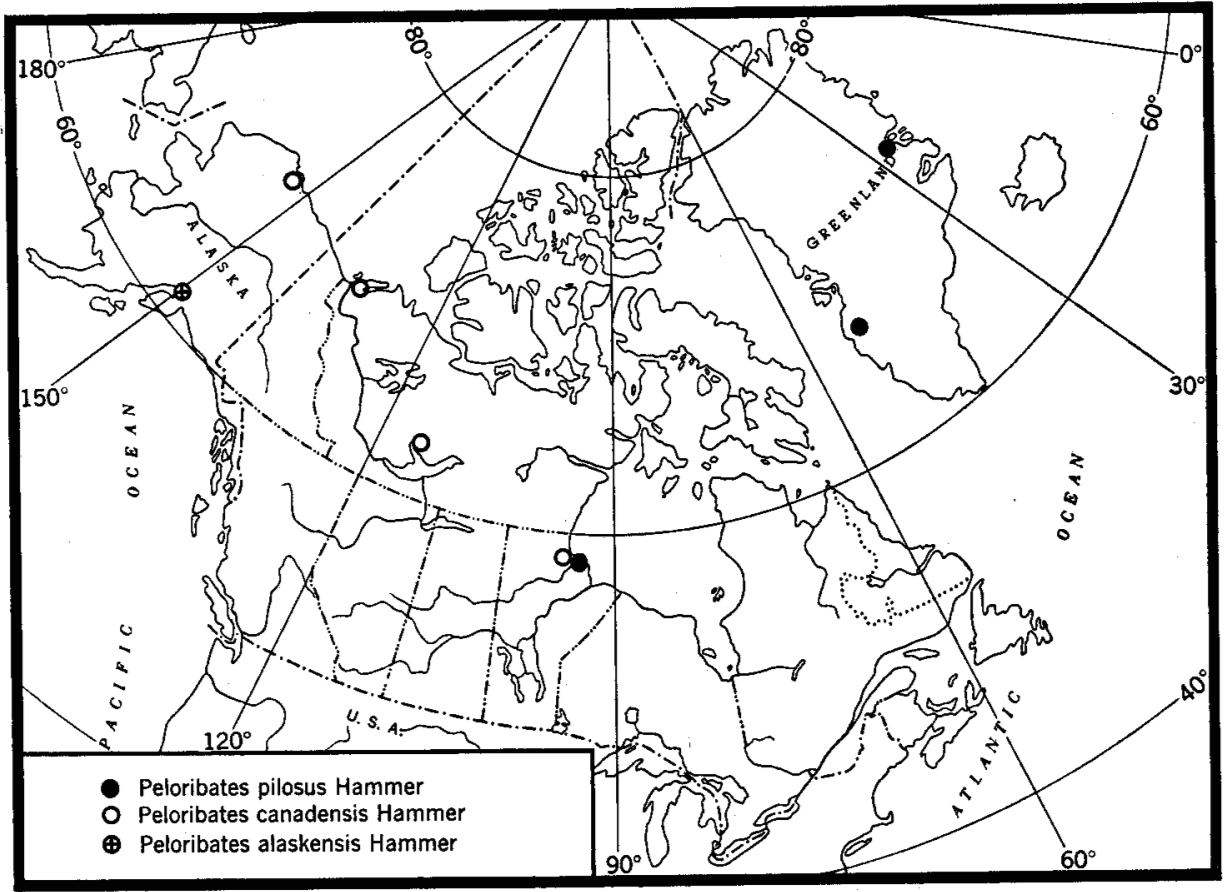

Fig. 7. Distribution of the genus Peloribates.

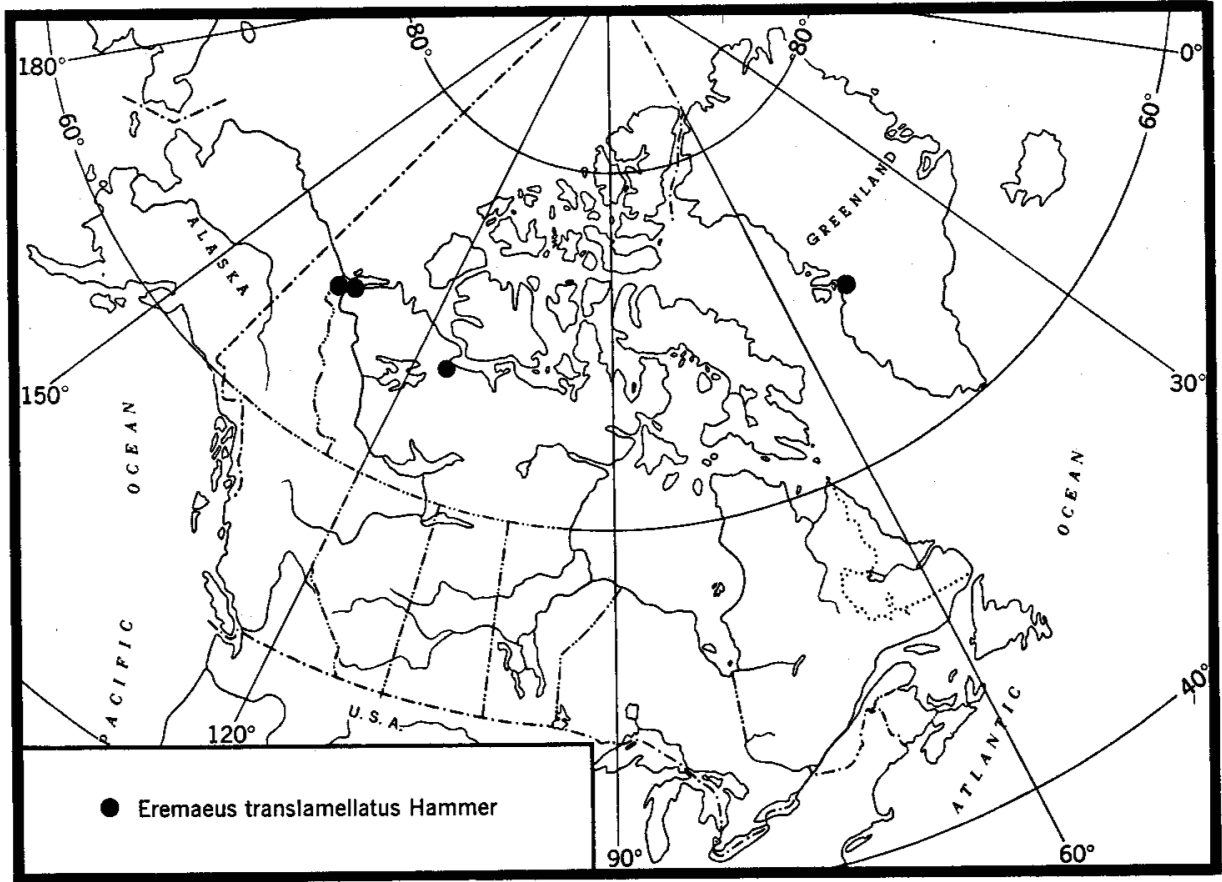

Fig. 8. Distribution of Eremaeus translamellatus Hammer. 


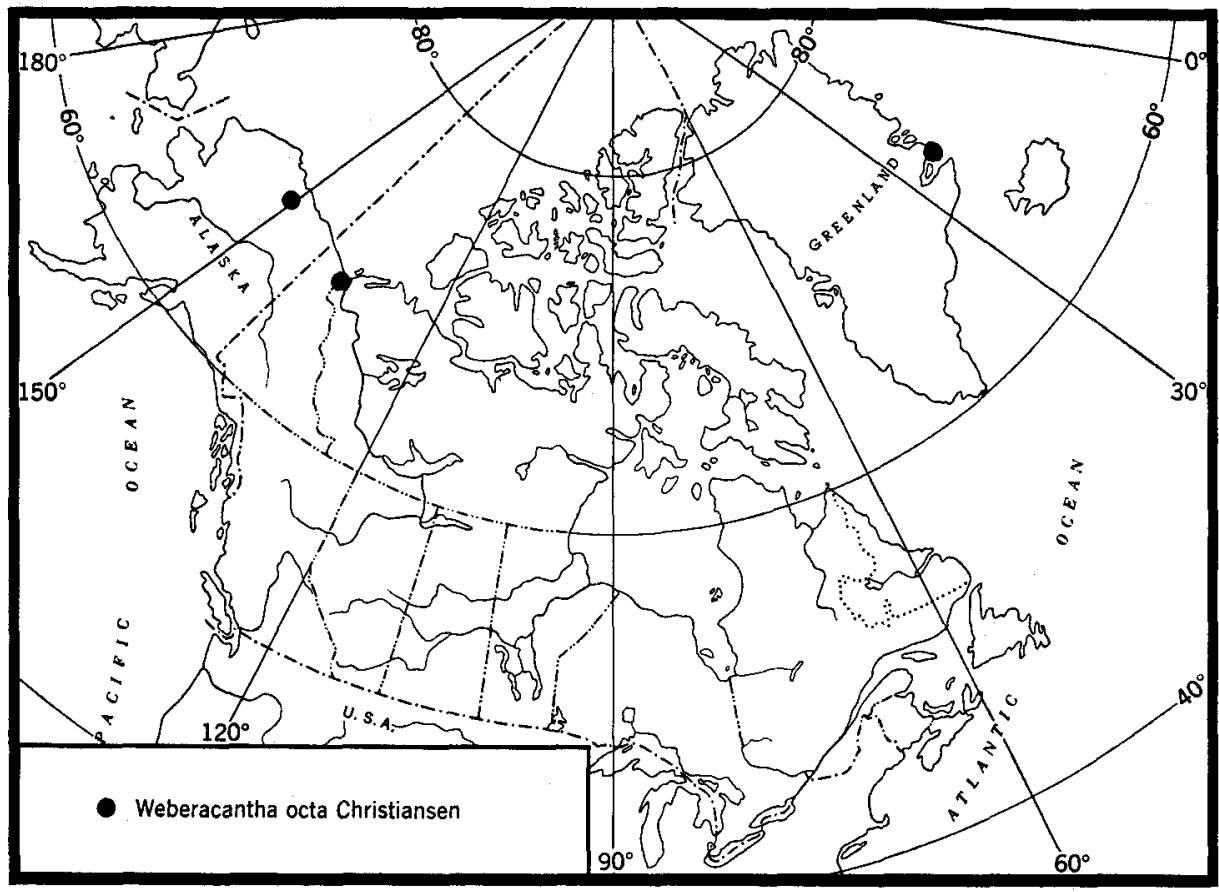

Fig. 9. Distribution of Weberacantba octa Christiansen.

This account deals with the large and distinctive genera only and none of the species described has been found in Europe. The smaller genera such as Brachychtbonius, Suctobelba, and Oppia are still relatively unknown and are so easily confused that their distribution cannot yet be discussed. However, it should be mentioned that $O$. clavigera Hammer, which has been found in lichen vegetation at Reindeer Depot, Coppermine, and Churchill in Canada, is comparatively numerous in Peary Land in a desert climate.

Certain highly specialized collembolan species show a distribution pattern in Canada and Greenland similar to that of the oribatids. Only a few species which can readily be identified are included.

Weberacantba octa Christiansen has been described from Alaska and from heath vegetation in the Richardson Mountains of northwestern Canada. Unlike most of the oribatids discussed, this characteristic collembole has not been found elsewhere in northern Canada, and in Greenland it has only been collected from Scoresby Sund in the extreme east (Hammer, 1953a, p. 82) (Fig. 9).

A new Folsomia species, $F$. regularis Hammer was recently found in a bog on Ellesmere Island. It has now been discovered in Peary Land where it was found on snow patches and in moss (Fig. 10).

When the distribution maps of species which occur only sporadically in Greenland are examined, it appears that these species must have come to Greenland by way of the Canadian arctic islands, where apart from a few 


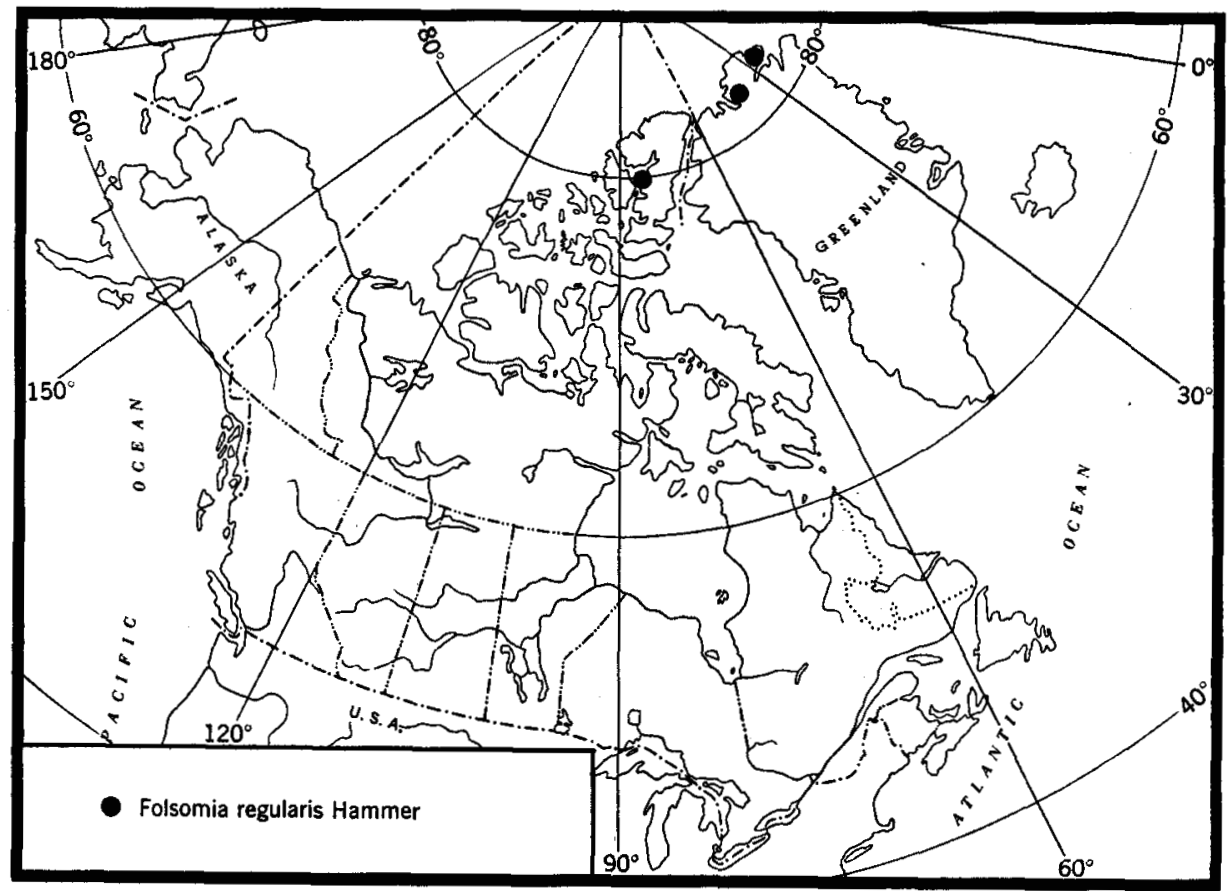

Fig. 10. Distribution of Folsomia regularis Hammer.

samples from Ellesmere Island, practically no collections have been made. None of these species has been found south of Scoresby Sund in east Greenland or south of Disko Bugt in west Greenland-apart from the interior of Søndre Strømfjord, where special climatic conditions prevail. The distribution pattern shows that these species do not tolerate the moist, oceanic climate of south Greenland. Unfortunately the Blosseville Kyst has not been investigated, and it is not possible to show that the climatic boundary is at about $68^{\circ} \mathrm{N}$., as suggested by Degerb $\phi 1$ (1937) from other faunal studies. As Greenland, particularly on the east coast, has been studied more closely than any other northern area, it seems more and more certain that these species are not found in Greenland south of $70^{\circ} \mathrm{N}$., but that they have a northern distribution. A few species including Fuscozetes sellnicki seem to be distributed from the northern coast of the Canadian mainland by way of Ellesmere Island to west Greenland. This pattern probably exists or existed for the other species mentioned. In some cases the continuity may have been broken by climatic changes so that there are now two widely separated distribution areas, as in the case of Weberacantba octa (Fig. 9).

These species, found sporadically in Greenland but which are widespread in northern Canada often with other species of the same genus, must be considered American-as long as nothing is known of their occurrence in Asia-and presumably emigrated to Greenland at a late date (interglacial or postglacial). The large group of species found in Greenland, which is 


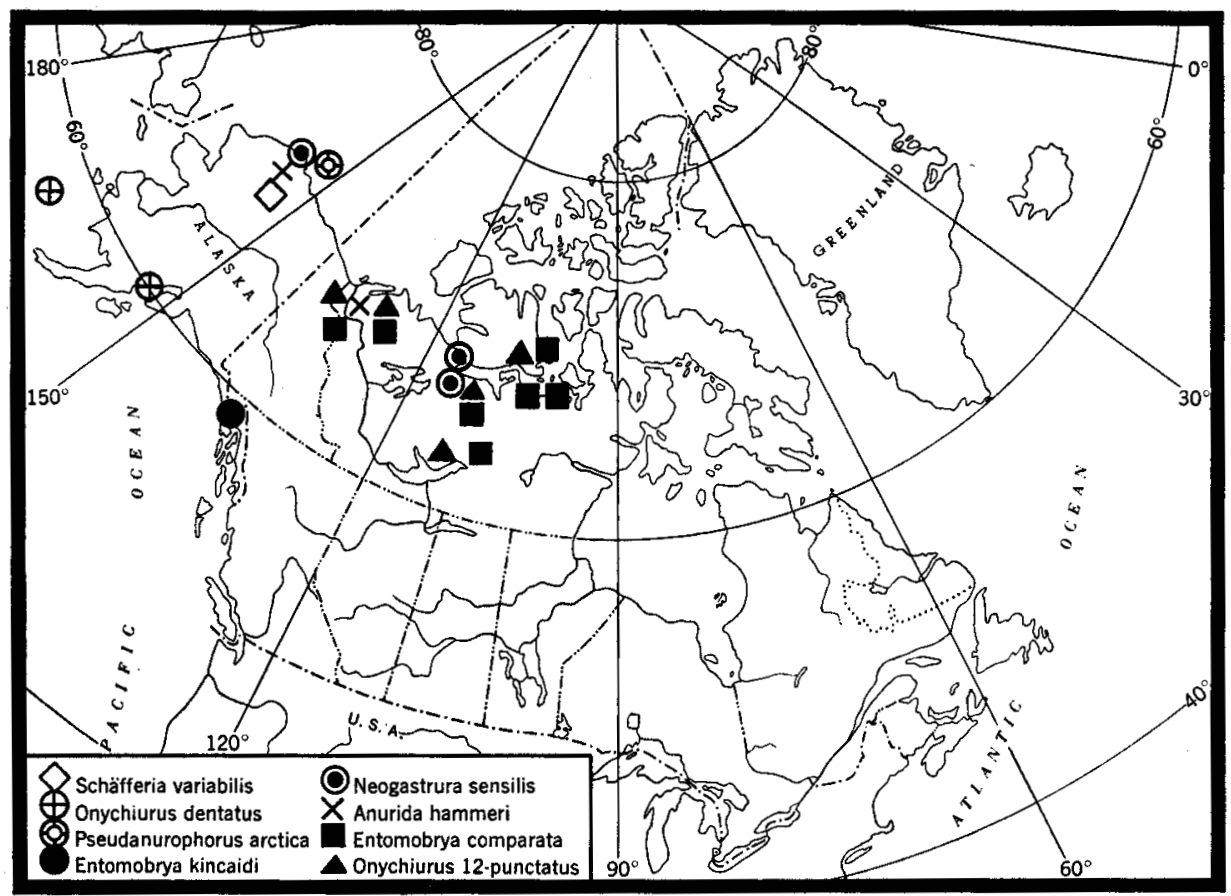

Fig. 11. Distribution of collembolan species known only from Alaska and northwestern Canada.

common to North America and Europe probably survived the Ice Age in Greenland.

There is no doubt that future research in the northern Canadian islands and northern Greenland will produce additional discoveries. For example, recently in a few Berlese samples from Ellesmere Island a collembole, Proisotoma mackenziana Hammer, was found which previously was only known from the Mackenzie delta. A new oribatid species, Trichoribates polaris Hammer was taken in the same material from Ellesmere Island, and has now been found in Alaska also (Hammer, 1955). In Greenland another oribatid, Belba groenlandica Hammer was found in Inglefield Land and has now been collected in Peary Land, where a new collembolan species, Micranurida polaris Hammer has also been found.

A number of collembolan species have been taken in Alaska and the northwest of Canada which have not so far been discovered anywhere else. These species are: Neogastrura sensilis (Folsom), Scbäfferia variabilis Christiansen, Anurida bammeri Christiansen, Onychiurus 12-punctatus Folsom, O. dentatus Folsom, Pseudanurophorus arctica Christiansen, Entomobrya kincaidi Folsom, and E. comparata Folsom; the distribution of these species is shown in Fig. 11. It must be assumed that as the majority of these species are comparatively large and distinctive, they are not widespread in North America where J. W. Folsom, the authority on collemboles, has worked for many years. 


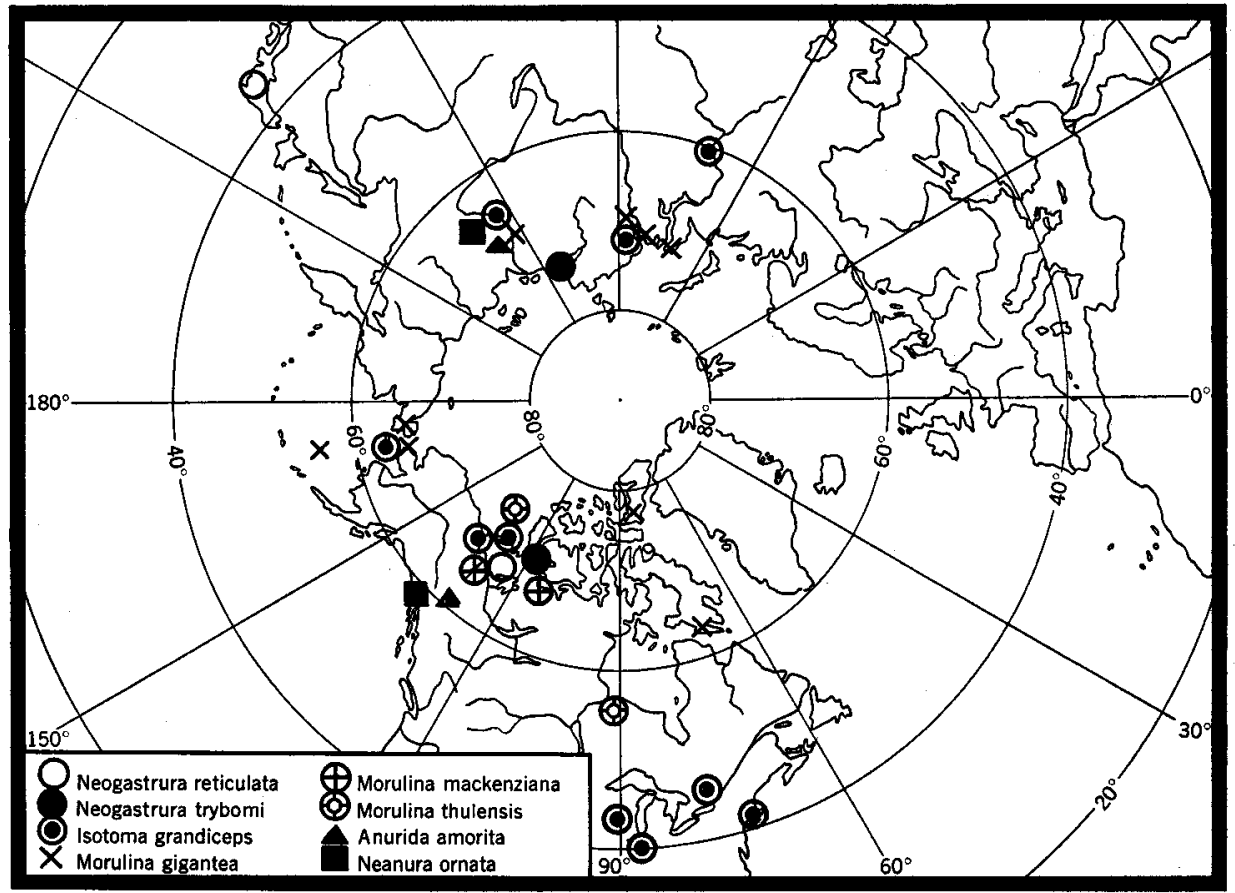

Fig. 12. Distribution of collembolan species known only from Asia, Alaska, and northern Canada (Isotoma grandiceps Reuter also known from the United States).

A few collembolan species have long been known from Siberia and Japan, and from some islands in Bering Strait. They are also found in Alaska and other parts of North America (Fig. 12). Neogastrura reticulata (Börner) has been found in Japan and the Mackenzie delta, N. trybomi (Schött) in northernmost Siberia and the Mackenzie delta, Anurida amorita Folsom and Neanura ornata Folsom are both known from Siberia and Alaska. In North America these four species have not been found east of the Mackenzie delta.

Some species have, however, spread farther east; Morulina gigantea (Tullb.), which is known from Siberia and islands in Bering Strait, has been reported from Baffin Island and Ellesmere Island, though there is some doubt about this identification. There are two other Morulina species in Canada, M. mackenziana Hammer known from the Mackenzie delta, and $M$. thulensis Hammer known from the Mackenzie delta and from Churchill. It is possible that the doubtful $M$. gigantea reported from eastern Canada is one of these species. In North America, as Fig. 12 shows, the Morulina species are only found in the north. Isotoma grandiceps Reuter, on the other hand, which is also found in northern Siberia, Bering Strait, and the Mackenzie delta, reaches the more southerly parts of North America. Both these collembolan species are probably Asiatic in origin and have emigrated to Alaska by way of Bering Strait, but while Morulina has spread farther east, I. grandiceps has penetrated south into the United States. 
It is not known why these large-sized species have failed to reach Greenland. A species of Morulina has, however, been found as far east as Ellesmere Island. A possible explanation is that the coldness and, particularly the dryness of the climate in the Canadian Arctic Archipelago and northwest Greenland, are a barrier to the farther eastward migration of the microfauna. This hypothesis is supported by investigations in Peary Land which show that in areas that are bare of snow in winter the fauna is extremely poor compared with the richer fauna in areas covered by drifted snow. It is also possible that the soils of Greenland are not rich enough to support these comparatively large-sized species. ${ }^{1}$

Most of the species discussed were found on the edge or immediately north of the tree-line in western Canada. Here, the summer temperature is far higher than on the migration route through the Canadian arctic islands to Greenland. But if cold summers along the migration route have prevented entry into Greenland, why have the species not penetrated southwards? The answer to this and the other problems must await further field investigations.

\section{References}

Degerb $\varnothing 1$, M. 1937. 'A contribution to the investigation of the fauna of the Blosseville Coast, with special reference to zoogeography'. Medd. om Grønl. Vol. 104, No. 19, $36 \mathrm{pp}$.

Hammer, Marie. 1944. 'Studies on the oribatids and collemboles of Greenland'. Medd. om Gronl. Vol. 141, No. 3, $210 \mathrm{pp}$.

1946. "Oribatids" in 'The zoology of east Greenland'. Medd. om

Grønl. Vol. 122, No. 1, 39 pp.

1952a. 'Investigations on the microfauna of northern Canada. Part

1: oribatidae'. Acta Arctica, Vol. 4, $108 \mathrm{pp}$.

1952b. "The oribatid and collembola fauna in some soil samples from

Søndre Strømfjord". Entomol. Medd. Vol. 26, No. 5, pp. 404-14.

1953a. 'Investigations on the microfauna of northern Canada. Part

2: collembola'. Acta Arctica, Vol. 6, 108 pp.

1953b. 'Collemboles and oribatids from the Thule district (northwest

Greenland) and Ellesmere Island (Canada)'. Medd. om Grønl. Vol. 136, No. 5, 16 pp. 1954a. 'Alaskan oribatids'. Unpublished MS.

1954b. 'Collemboles and oribatids from Peary Land (north Greenland)'.

Medd. om Gronl. Vol. 127, No. 5, $28 \mathrm{pp}$.

Mills, H. B. and W. R. Richards. 1953. "Collembola from arctic and boreal Canada". J. Kansas Entomol. Soc. Vol. 26, pp. 53-9.

Strenzke, K. von. 1952. "Zur Systematik westgrönländischer Oribatiden". Zool. Anz. Vol. 149, Nos. 3-4, pp. 89-96.

${ }^{1}$ Large species require good soil, and generally the poorer the soil, the smaller the species. This is well shown in the difference between extraordinarily large collembolan species and richer presentation of Onychiuridae in the fertile Mackenzie delta, and the few large species, almost no Onycbiuridae, and many individuals of the small Tullbergia in the rocky terrain of Yellowknife (Hammer, 1953a, pp. 67-8). 